\title{
2 Influence of upwelling on the sedimentation and biota of the 3 segmented margin of the western Neotethys: a case study from the 4 Middle Triassic of the Balaton Highland (Hungary)
}

\author{
5 Tamás Budai ${ }^{1} \cdot$ János Haas $^{2} \cdot$ Attila Vörös $^{3} \cdot$ Zsuzsa Molnár $^{4}$
}

6 Received: 17 November 2016 / Accepted: 23 June 2017

7 (c) Springer-Verlag GmbH Germany 2017

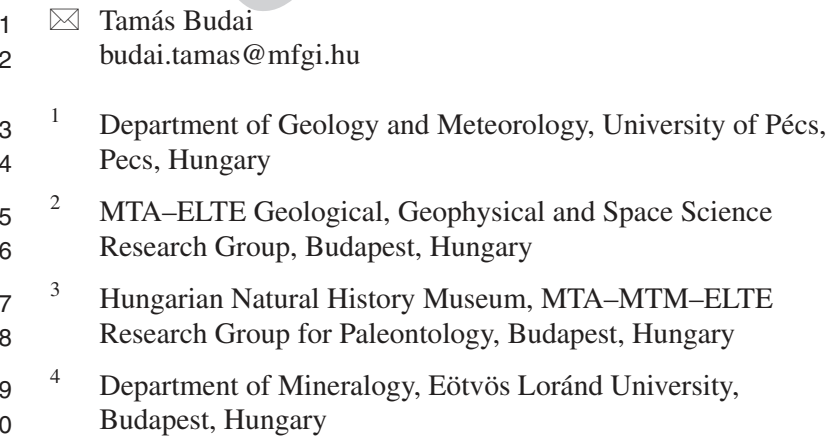

Abstract In the Middle Anisian, extensional tectonic movements led to the development of a small isolated carbonate platform in the middle part of the Balaton Highland, Transdanubian Range, Hungary. In the Late Illyrian, a condensed pelagic carbonate succession with phosphorite horizons was formed on the top of the already drowned platform. These strata contain an extraordinarily diverse ammonite fauna. This unit is overlain by radiolarian-rich carbonates, locally with radiolarite interbeds. We suggest that the drowning process and the post-drowning sediment deposition were controlled partly by regional factors, i.e., the onset of opening of the Neotethys Ocean, and partly by local factors such as the bottom topography and related current activity, which may also be connected with the opening of the ocean. The predominance of the radiolarian-rich sediments suggests eutrophic surface water, which may be explained by a monsoon-driven upwelling model. The segmented sea-floor topography together with the high-fertility surface water conditions may have provided favorable habitats for the ammonites, which may have adapted to various ecological conditions, leading to extreme diversification of this group. Since similar Middle to Late Anisian evolution was reported from many other units of the western Neotethys margin, regional factors such as the establishment of an extensional tectonic regime and related marginal basin formation, monsoon-driven upwelling, and related high surface water productivity seem to be of critical importance in controlling the depositional conditions.

Keywords Sea-floor topography $\cdot$ Submarine high ·

Radiolarite $\cdot$ Phosphorite $\cdot$ Diversity peak .

Monsoon-driven upwelling $\cdot$ Neotethys margin $\cdot$ Middle

Triassic $\cdot$ Balaton Highland

\section{Introduction}

Detailed study of the Triassic series of the Balaton Highland goes back more than a hundred years. It was Lóczy sen. (1916) who first recognized that the "Alpine Muschelkalk" (=Felsöörs Fm) of the Middle Triassic succession of the Balaton Highland is substituted by an "Esino-type" shallow-marine limestone (=Tagyon Fm) in the middle part of the area.

During the 1950s, uranium-ore exploration was performed on the Balaton Highland. The target sequence was the Upper Permian fluvial sandstone (=Balatonfelvidék Fm), however, an unexpected uranium enrichment was found connecting to phosphorite horizons in the Middle Triassic succession (=Vászoly Formation) in the middle part of the Balaton Highland (Kiss and Virágh 1959). For detailed studies of the sequence, trenches and shafts were excavated and boreholes were drilled in the surroundings of Vászoly, Pécsely, Örvényes, and Aszófó. The Middle Triassic sequence of the area was briefly presented by Szabó (1972), however, detailed data of the exploration have not been published.

In the 1980s, a geological mapping project was carried out on the Balaton Highland (Budai et al. 1999a, b).
36

\begin{tabular}{l|lll|} 
Journal : Large $\mathbf{1 0 3 4 7}$ & Dispatch : 29-6-2017 & Pages : $\mathbf{1 7}$ \\
Article No : $\mathbf{5 0 4}$ & $\square$ LE & $\square$ TYPESET \\
MS Code : FACI-D-16-00067 & $\square \quad$ CP & $\square$ DISK \\
\hline
\end{tabular}


This resulted in studies on lithostratigraphy (Budai 1992), bio-chronostratigraphy of the Middle Triassic succession (Dosztály 1993; Góczán and Oravecz-Scheffer 1993; Kovács 1993; Kovács et al. 1990; Vörös 1993, 1998) and reconstruction of the basin evolution (Budai and Vörös 1992, 1993; Budai and Haas 1997; Budai and Vörös 2006). Diversity changes and paleoenvironmental significance of Middle Triassic ammonoids and other fossil groups were presented by Vörös $(1996,2002,2009,2014)$ and Vörös et al. (2003).

The geological mapping program and the detailed stratigraphic, sedimentological, and palaeontological studies of selected sections resulted in the recognition and reconstruction of a small isolated carbonate platform in the central part of the Balaton Highland. It was formed in the Middle Anisian (Pelsonian) as a result of tectonically controlled segmentation of the previously uniform carbonate ramp (Budai and Vörös 1992; Budai and Haas 1997). These studies also revealed the Late Anisian (Illyrian) drowning of this platform and the peculiar features of the overlying succession, which was formed on post-drowning submarine high and the extremely high diversity of the ammonite fauna of this bed set. On the basis of these investigations, here we evaluate the depositional environments and the processes of sediment deposition and try to explain the cause of the extreme diversity.
The main aim of the present paper is to summarize the inferences of the studies performed in the course of uranium exploration and geological mapping in the middle part of the Balaton Highland during last half century. Some of the results of these studies were previously published but most of them have never been published. These field observations and analytical data were complemented with the results of new investigations including the microfacies analysis of carbonates and mineralogical and geochemical studies of the phosphorites. We involved so far unpublished data on the radiolarian fauna and previous but unpublished and new data on the ammonoids to improve the exactness of the stratigraphic subdivision and evaluate the abundance and diversity of the assemblages. To give a complex interpretation of the available data, we took into account paleogeographic considerations and the results of studies of modern oceanographic analogues.

\section{Geological setting}

The study area is located in the middle part of the Balaton Highland on the south-eastern flank of the NE-SWtrending synform of the Transdanubian range unit (Fig. 1). Its structure (Fig. 2) differs from those in the other parts of the Balaton Highland. The SW-NE general strike of the

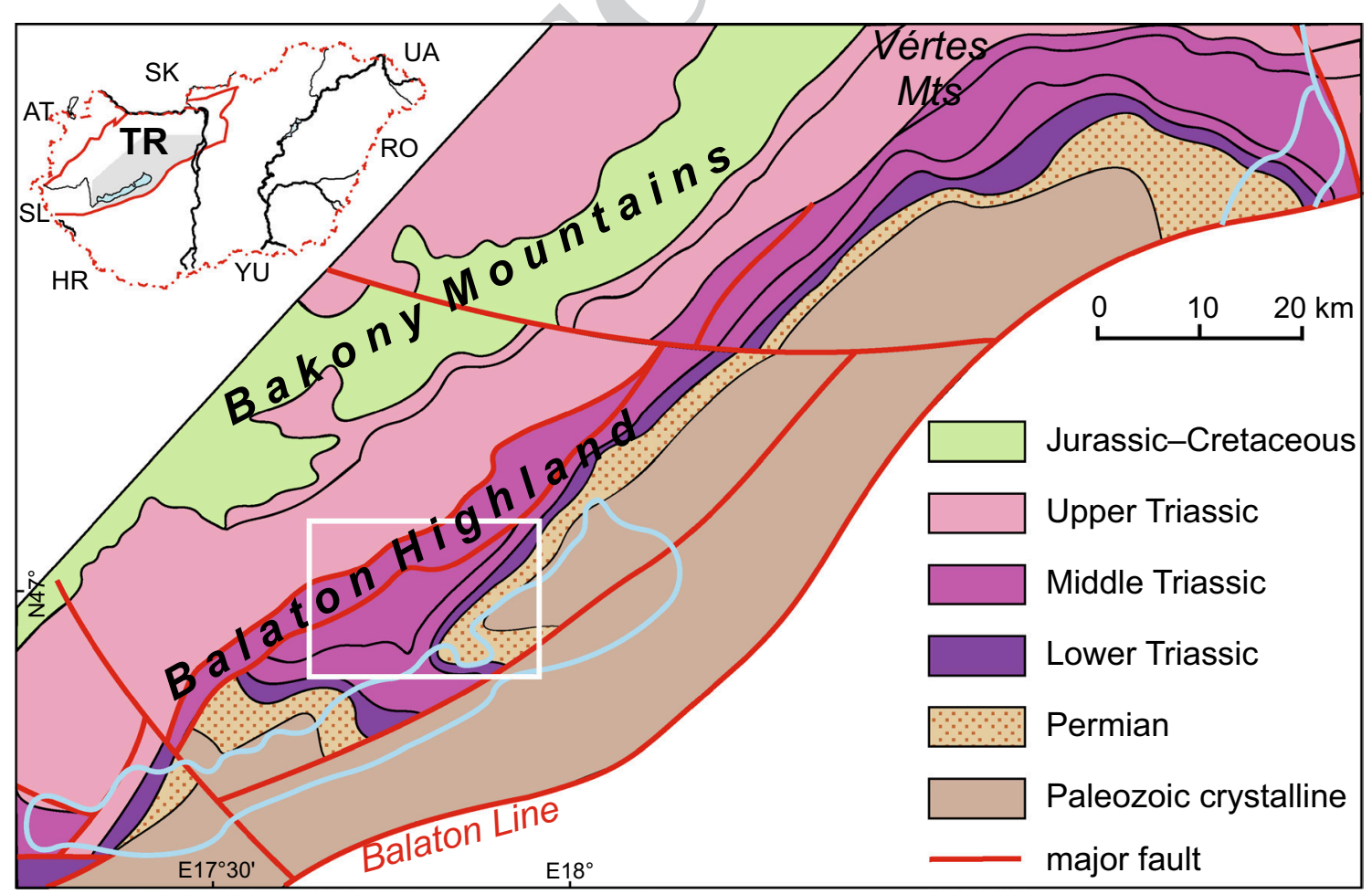

Fig. 1 Pre-Cenozoic geological map of the middle part of the Transdanubian range unit (simplified after Haas et al. 2010). The rectangle shows the site of the study area in Fig. 2

\begin{tabular}{llll|} 
Journal : Large 10347 & Dispatch : 29-6-2017 & Pages : 17 \\
Article No : $\mathbf{5 0 4}$ & $\square$ LE & $\square$ TYPESET \\
MS Code : FACI-D-16-00067 & $\square \quad C P$ & $\square$ DISK \\
\hline
\end{tabular}




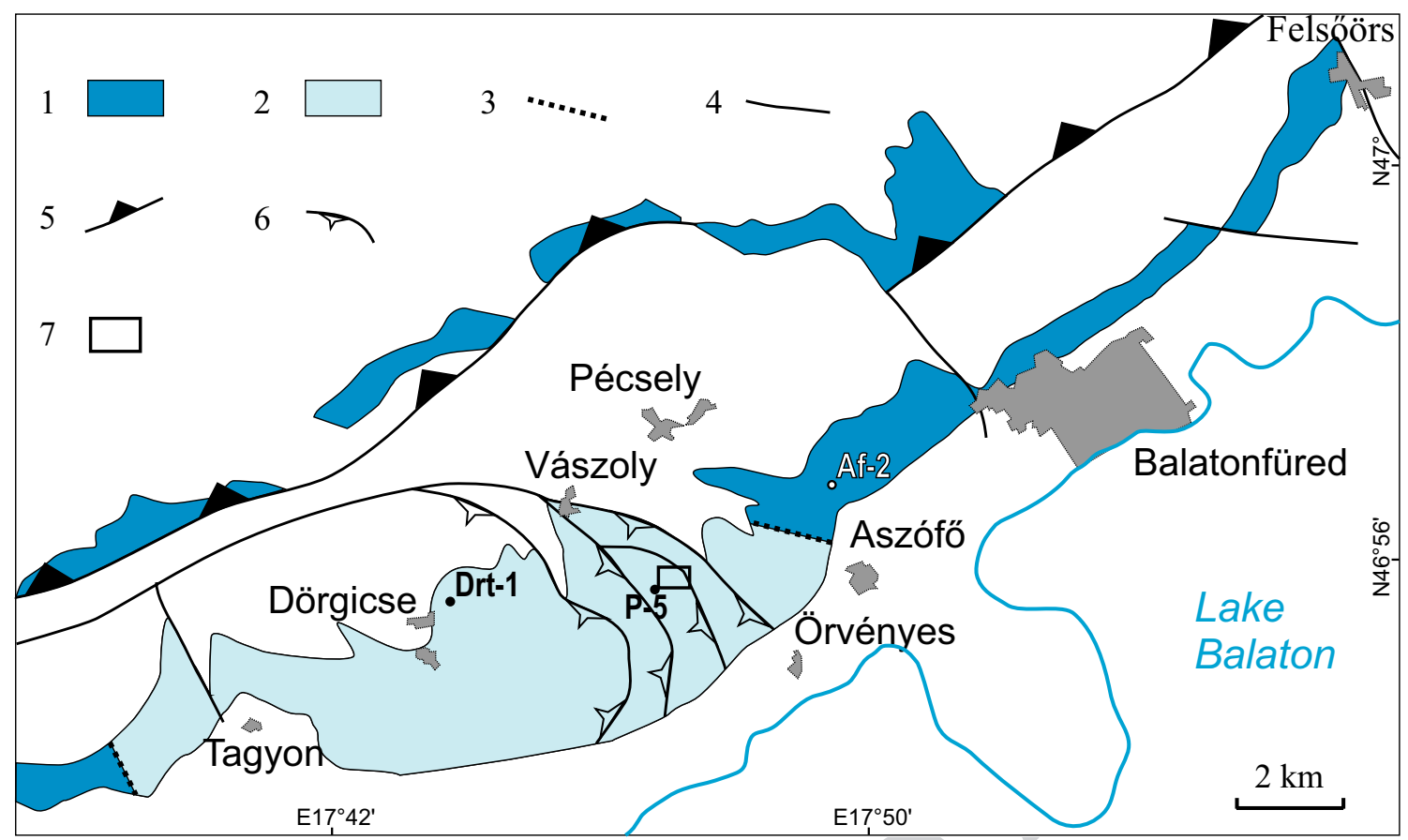

Fig. 2 Areal extent of the Middle Anisian to Lower Carnian formations in the middle part of the Balaton Highland (modified after Budai and Vörös 2006). 1 Area characterized by Pelsonian basinal deposits; 2 Area characterized by Pelsonian platform deposits; 3
Boundary of the Pelsonian Felsőörs Basin and the Tagyon Platform; 4 Fault; 5 Litér thrust; 6 Transverse thrusts ("Dörgicse horse-tail structure"); 7 Location of the area shown in Fig. 4. Drilled cores: Aszófó Af-2; Dörgicse Drt-1; Pécsely P-5
Triassic formations turns here into NW-SE direction and the Middle Anisian to Ladinian sequence is repeated several times by transverse thrust faults (Fig. 2) forming the so-called "Dörgicse horse-tail structure" (Dudko in Budai et al. 1999b).

The Middle Triassic sequence of this area also shows some unique features, which do not occur in other parts of the Balaton Highland (Fig. 3). The Pelsonian hemipelagic basinal strata of the Felsőörs Limestone are replaced here by coeval platform carbonates of the Tagyon Formation (Budai and Haas 1997). This lateral facies change is explained by synsedimentary extensional tectonics forming halfgraben-type hemipelagic basins and isolated carbonate platforms in the area of the Transdanubian Range during the Pelsonian (Budai and Vörös 1992). As a result of a relative sea-level rise, the Pelsonian Tagyon Platform was drowned and transformed to a submarine high (Tagyon High); the first overlying layers above it belong to the upper Illyrian Camunum Subzone (Budai and Vörös 2006). This event was followed by deposition of the Upper Anisian-Ladinian sequence with phosphorite horizons and radiolarite layers on the top of the submarine high. Based on data of the uranium-ore exploration project and the detailed geological mapping (Budai et al. 1999b), phosphorites are known only at the north-eastern margin of the Tagyon High, at Öreg Hill, near Vászoly. Radiolarites and radiolarian-rich carbonates occur more widely: in addition to the area of the Tagyon High, they are also known from the eastern part of the Felsöörs Basin located in the proximity of the high at Aszófó (Fig. 3). An Upper Ladinian ammonoid assemblage in a neptunian dyke cutting through the Middle Triassic platform carbonates in the north-eastern part of the Balaton Highland (Budai and Vörös 2006) proves the prolongation of the extensional tectonic regime at least until the end of the Middle Triassic.

\section{Materials and methods}

For the microfacies characterization of the Vászoly Formation and the Buchenstein Formation, 103 thin-sections were prepared from different lithofacies in the course of geological mapping of the Öreg Hill (Vászoly) area, but, their upto-date microfacies analysis has not been carried out until now. A further nine thin-sections were prepared and studied from the profile of the trench $\mathrm{P}-11$ to get more details on the microfacies of the phosphoritic layers. Each of the phosphorite horizons was sampled for total organic content (TOC) analyses that were performed in the laboratory of the Geological and Geophysical Institute of Hungary.

For mineralogical studies, five samples were collected and analyzed. Quantitative electron microprobe analyses of

\begin{tabular}{|llll|} 
Journal : Large 10347 & Dispatch : 29-6-2017 & Pages : 17 \\
Article No : $\mathbf{5 0 4}$ & $\square$ LE & $\square$ TYPESET \\
MS Code : FACI-D-16-00067 & $\square \quad C P$ & $\square$ & DISK \\
\hline
\end{tabular}




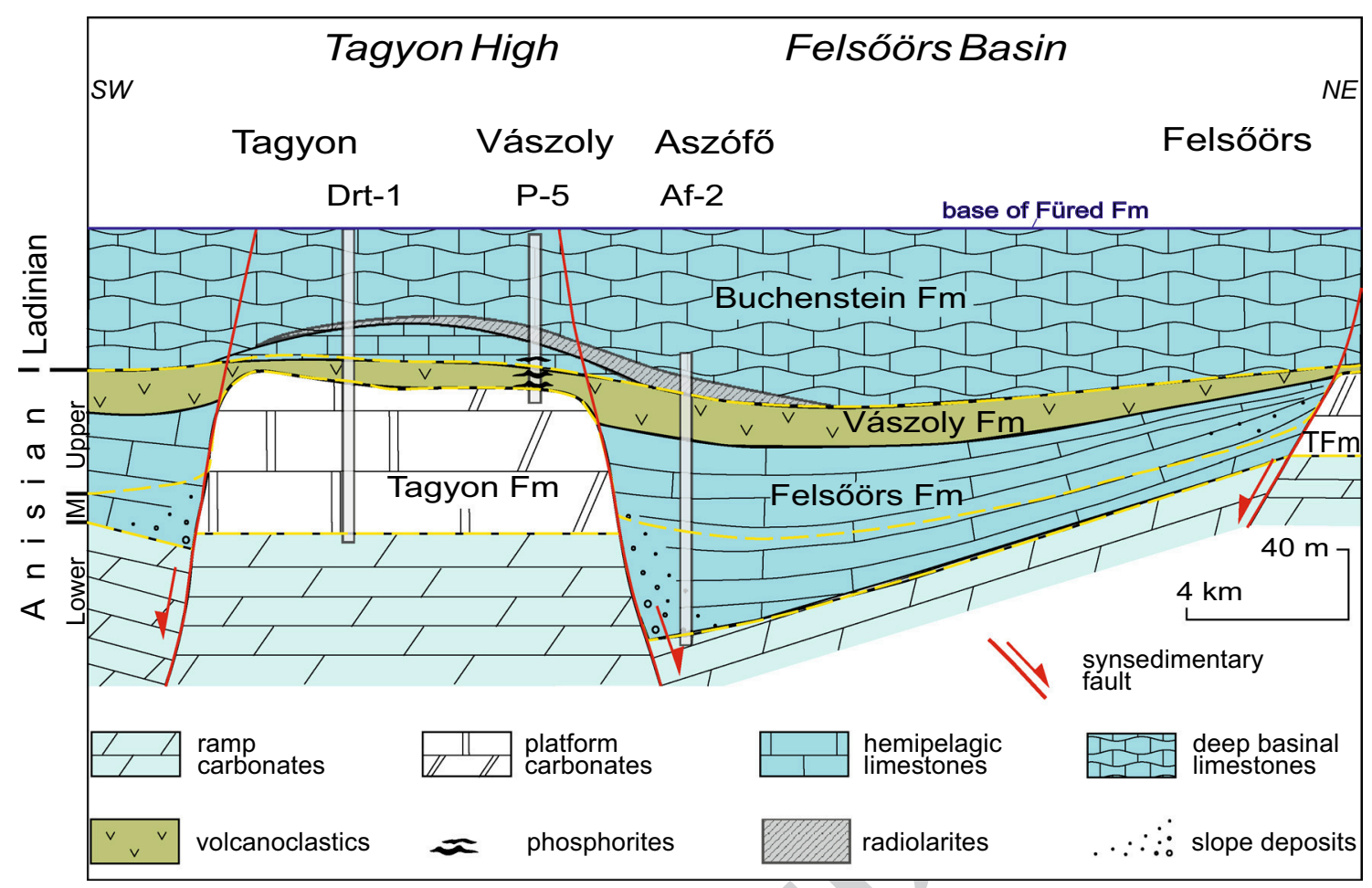

Fig. 3 Balanced geological cross section along the Balaton Highland showing the lateral and vertical connections of the Middle Triassic formations of the Tagyon Platform (later the submarine Tagyon High)

apatite were completed in the Eugen F. Stumpfl Microprobe Laboratory of the University of Leoben with a JEOL Superprobe JXA 8200-type electron microprobe. Wavelength dispersive mode was used, with 15-kV 208 accelerating voltage and $10-n A$ beam current.

The bulk rock ICP-MS (for trace elements) and ICP-OES (for major and minor elements) analyses were carried out in the Geological and Geophysical Institute of Hungary. ICPOES analyses were carried out with a Jobin-Yvon Ultima 2C-type spectrometer, equipped with a monochromator, while the ICP-MS analyses by an ELAN DRC II mass spectrometer. Lithium borate was used to fuse the samples. The in situ measurements of apatite were performed by laser-ablation single-collector sector-field inductively coupled plasma mass spectrometry using a Thermo Finnigan Element 2 mass spectrometer coupled to a Resonetics Excimer laser ablation system at the University of Göttingen.

\section{Results}

This section contains the summary of the results of our sedimentological and mineralogical investigations of the Upper Anisian-Ladinian succession. and the Felsöörs Basin and the sites of relevant boreholes (modified after Budai and Vörös 2006). Yellow dashed line stage boundary

Vászoly Formation (Upper Illyrian to Lower Ladinian)

The Upper Illyrian tuff-bearing basinal succession (Vászoly Formation) was exposed by several trenches and shafts on the Öreg Hill, near Vászoly (Fig. 4) and was the subject of detailed paleontological and biostratigraphical studies along the trench P-11a (Figs. 5, 9) by Vörös and Pálfy (1989), Kovács et al. (1990), and Vörös (1998).

This succession, which was deposited on the Tagyon High after the drowning event (Vászoly, Öreg Hill, P-5 core), shows much more varied lithology than that of the coeval sequences (Aszófö Af-2 core) in the Felsőörs Basin (Fig. 5). It is made up of alternation of ammonite- and brachiopod-rich limestone and dolomite beds and volcanic tuff layers. The limestone beds are characterized by bioclastic wackestone/packstone texture (Fig. 6a, b). They are rich in radiolarians (micrite or finely crystalline sparitefilled moulds of radiolarians) and fragments of thin-shelled bivalves ("filaments"). Crinoid ossicles are common; echinoid spines, foraminifera, and ostracods also occur. The limestone is locally dolomitized. The sedimentary fabric is partly or completely destructed in the dolomitized layers or patches. The dolomite is unimodal, finely crystalline, planar-euhedral, or -subhedral (Fig. 6c).

This bed set is punctuated by phosphoritic horizons and overlain by light yellowish-grey bedded limestone

\begin{tabular}{|l|lll|}
\hline Journal : Large 10347 & Dispatch : 29-6-2017 & Pages : 17 \\
Article No : $\mathbf{5 0 4}$ & $\square$ LE & $\square$ TYPESET \\
MS Code : FACI-D-16-00067 & $\square \quad$ CP & $\square \quad$ DISK \\
\hline
\end{tabular}




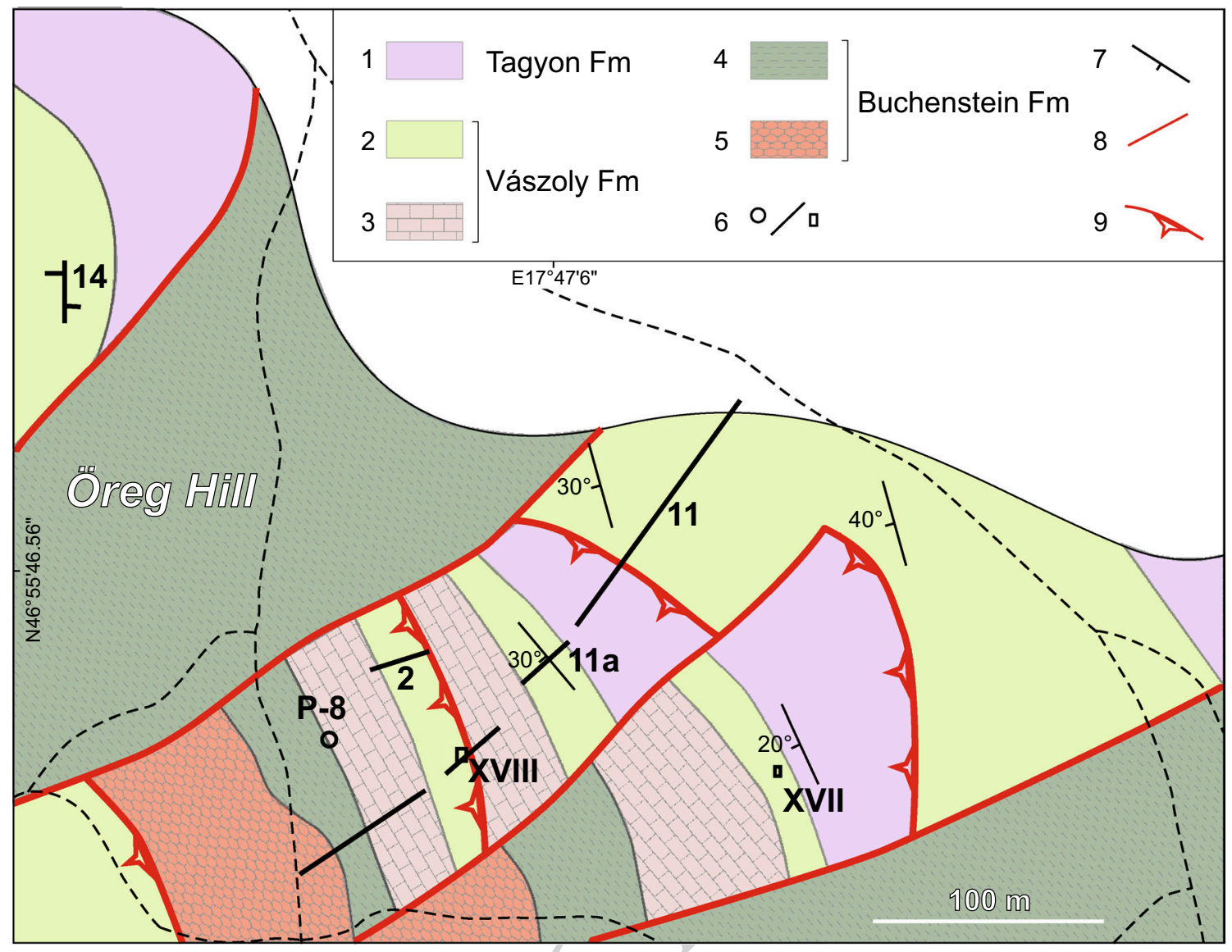

Fig. 4 Geological map of Öreg Hill, south of Vászoly, showing the artificial exposures for the U-exploration (based on field observations of T. Budai and an unpublished map of I. Szabó). Middle Anisian (Pelsonian): 1 Thick-bedded dolomite; Upper Anisian (Upper Illyr- ian): 2 tuff, limestone, dolomitic limestone; Ladinian: 3 light grey, bedded limestone; 4 laminated, siliceous tuff, radiolarite; 5 nodular cherty limestone; 6 borehole, trench, shaft; 7 dip; 8 fault; 9 thrust fault
(Fig. 5) of bioclastic wackestone texture with a large amount of fragments of thin-shelled bivalves. The brownish-grey uranium bearing phosphorite layers of the Upper Illyrian sequence of the Öreg Hill (Vászoly) appear in three stratigraphic horizons (Fig. 5). The lowermost horizon occurs at the drowning surface of the Pelsonian platform carbonates (Tagyon Formation) and the overlying Upper Illyrian tuffaceous carbonate beds of the Vászoly Formation. Upsection the phosphorite appears in the form of coating around bioclasts and infilling of biomolds in reddish or purple, organic-rich limestone (TOC 0.58$0.77 \%$ ) of the lower member of the Vászoly Formation (Fig. 6d). The uppermost phosphorite horizon occurs in the form of dark greenish-grey crusts on the bedding-surfaces of the light grey bedded limestone in the upper part of the Vászoly Formation (Fig. 6e, f). The thicknesses of these irregular phosphoritic bodies randomly vary even in short distance; their maximum thickness $(1.2 \mathrm{~m})$ was documented in $\mathrm{P}-14$ trench (Fig. 4).
The main minerals found in the phosphorite-bearing layers are apatite and calcite, but hematite, pyrite, and zircon are scarcely present, locally. The apatite usually occurs around calcitic grains, whereas the remaining space is filled by calcite cement. Based on quantitative EPMA analyses, the exact chemical composition of the apatite is $\left(\mathrm{Na}_{0.565} \mathrm{Ca}_{4.435}\right)_{5}\left[\left(\mathrm{PO}_{4}\right)_{2.435}\left(\mathrm{CO}_{3}\right)_{0.565}\right]_{3} \mathrm{~F}$, indicating that carbonate-bearing fluorapatite (CFA) is the main mineral phase (Molnár et al. 2016). According to the electron probe micro analyses (EPMA), the $\mathrm{U}$ enrichment is most likely related to the CFA, U-bearing separate mineral phase was not found. According to LA-ICP-MS study of the uppermost phosphorite horizon, the CFA contains 137-612 ppm $\mathrm{U}$ and 113-261 ppm total REE + Y. Th with redox-sensitive elements (U, V) are used in monitoring detrital input. The correlation between $\mathrm{Th}-\mathrm{U}$ and $\mathrm{Th}-\mathrm{V}$ are $R_{\mathrm{Th}}^{2}$ $\mathrm{U}=-0.71$ and $R_{\mathrm{Th}-\mathrm{V}}^{2}=-0.48$. The redox-sensitive proxies such as $\mathrm{Th} / \mathrm{U}$ and $\mathrm{V} / \mathrm{Cr}$ ratios of CFA are used to discuss the sedimentary environment (Wignall and Twichett 1996;

\begin{tabular}{|l|ll|} 
Journal : Large 10347 & Dispatch : 29-6-2017 & Pages : 17 \\
Article No : $\mathbf{5 0 4}$ & $\square$ LE & $\square$ TYPESET \\
MS Code : FACI-D-16-00067 & $\square \quad C P$ & $\square \quad$ DISK \\
\hline
\end{tabular}


Fig. 5 Stratigraphic column of the Middle Anisian-Ladinian sequence of the Tagyon High at Vászoly ( $\mathrm{P}-5$ core of Öreg Hill, N46 $55^{\prime} 37.9^{\prime \prime}$ E17 $46^{\circ} 49^{\prime \prime}$ ) and the coeval Felsöörs Basin at Aszófó (Af-2 core, N46 $56^{\prime} 43.5^{\prime \prime}$ E17 ${ }^{\circ} 49^{\prime} 24.3^{\prime \prime}$ ) (after Szabó 1972; Budai et al. 1999b). Numbers refer to Figs. 6, 7, and 8, and point to the stratigraphic position of the presented lithofacies types. Detailed column of $\mathrm{P}-11 \mathrm{a}$ trench (N46 $55^{\prime} 44.7^{\prime \prime} \mathrm{E} 17^{\circ} 47^{\prime} 05.5^{\prime \prime}$ ) is shown on Fig. 9. 1 Ramp dolomite; 2 Platform dolomite; 3 Hemipelagic basinal limestone and marl; 4 Tuffaceous limestone, crinoidal limestone; 5 Volcanoclastics; 6 light grey bedded limestone; 7 siliceous volcanic tuff, radiolarite; 8 nodular, bedded (cherty) limestone; 9 Posidonia-rich laminated limestone; 10 phosphorite lenses, impregnations. Bith.

Bithynian (Lower Anisian); Pel. Pelsonian (Middle Anisian)

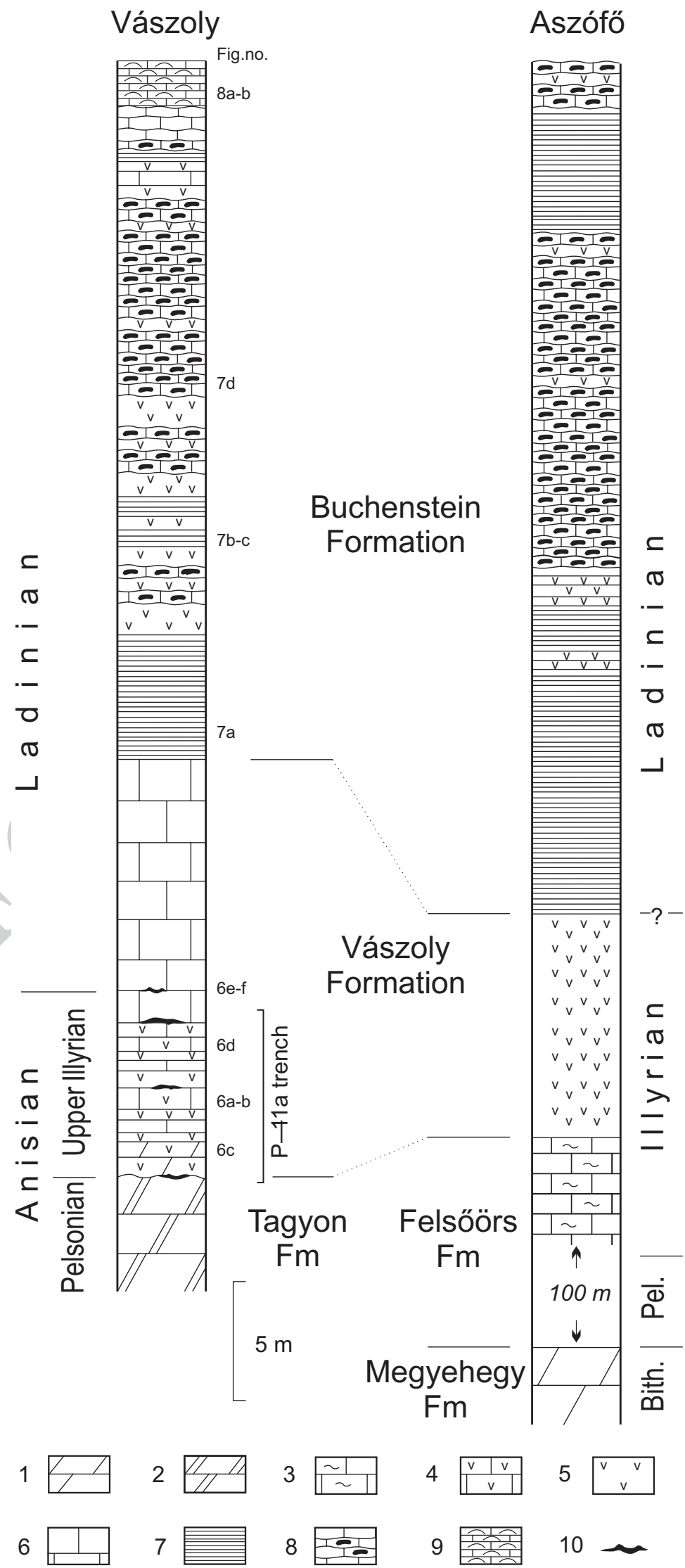

\begin{tabular}{|llll|} 
Journal : Large 10347 & Dispatch : 29-6-2017 & Pages : 17 \\
Article No : $\mathbf{5 0 4}$ & $\square$ LE & $\square$ TYPESET \\
MS Code : FACI-D-16-00067 & $\square \quad C P$ & $\square \quad$ DISK \\
\hline
\end{tabular}



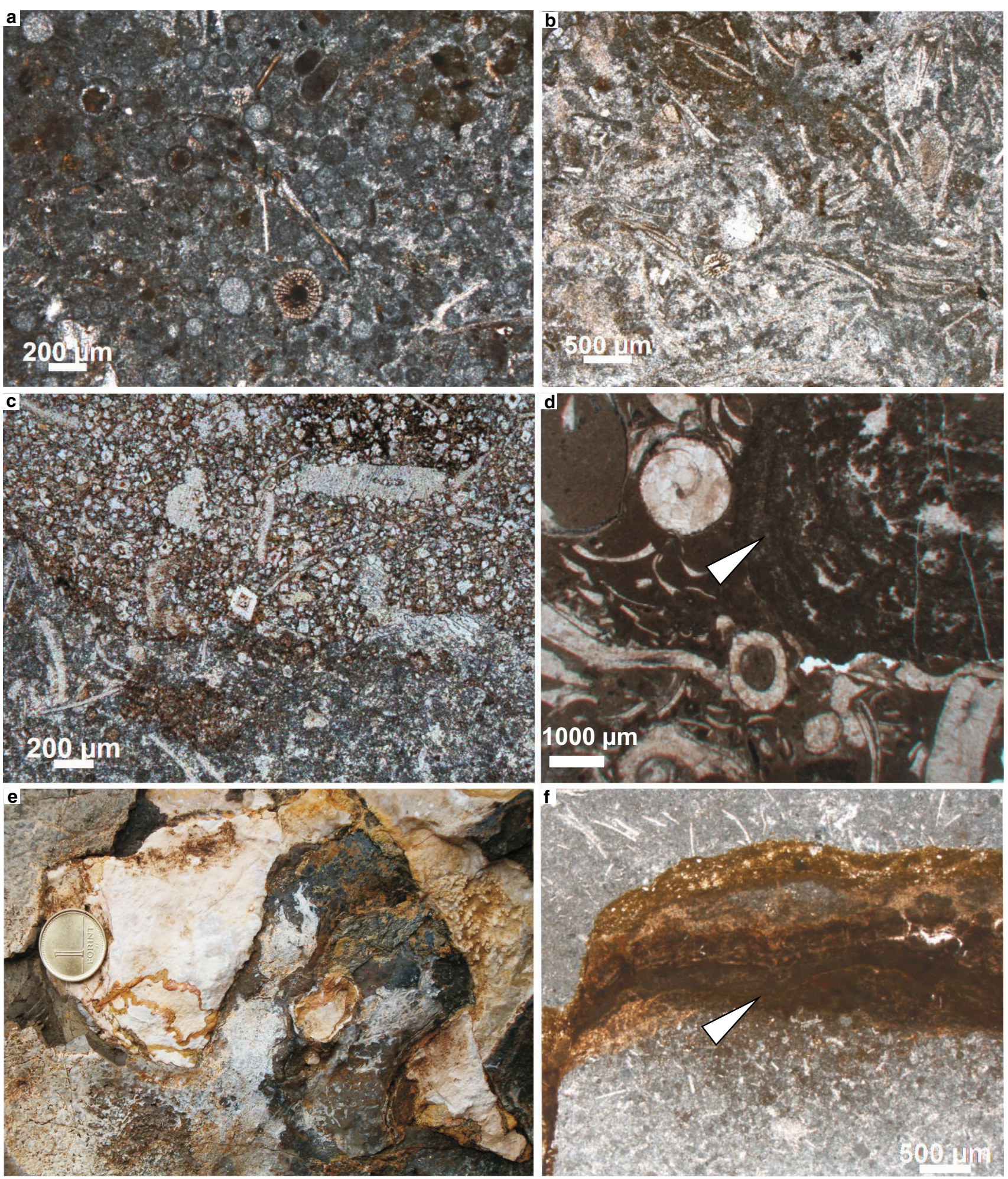

Fig. 6 Lithofacies types of the Vászoly Formation (Upper Illyrian) of the Tagyon High, Vászoly, Öreg Hill, P-11a trench. a Photomicrograph of radiolarian packstone with fragments of crinoids, echinoid spines, and fragments of molluscs. The moulds of radiolarians are filled by microsparite. b Photomicrograph of bioclastic wackestone with fragments of thin-shelled bivalves ("filaments") and crinoids. c Partially dolomitized bioclastic wackestone. d Photomicrograph of bioclastic wackestone with fragments of thick-shelled gastropods, bivalves, and oncoid-phosphorite (arrow). e Dark greenish-grey phosphoritic hardground in the uppermost part of the Vászoly Formation (lowermost Ladinian, Curionii Zone), diameter of the coin is $1.5 \mathrm{~cm}$. f Microphotograph of wavy laminated phosphorite-crust (stromatolite cover) on an uneven hardground (arrow). Bioclastic wackestone with fragments of thin-shelled bivalves occur both below and above the hardground

\begin{tabular}{l|lll|} 
Journal : Large $\mathbf{1 0 3 4 7}$ & Dispatch : 29-6-2017 & Pages : $\mathbf{1 7}$ \\
Article No : $\mathbf{5 0 4}$ & $\square$ LE & $\square$ TYPESET \\
MS Code : FACI-D-16-00067 & $\square \quad C P$ & $\square$ & DISK \\
\hline
\end{tabular}


Jones and Manning 1994). Th/U ratio is always lower than 1 in the studied samples, while the $\mathrm{V} / \mathrm{Cr}$ ratio is always more than 4.25 in the same sample. The Y/Ho ratio of CFA from Pécsely shows a variation from 33.9 to 55.7.

\section{Buchenstein Formation (Ladinian)}

Radiolarites occur all over the area of the Tagyon High mostly in the lower part of the Buchenstein Formation (Fig. 7a-c). However, they are much thicker in the northeastern part of the Tagyon High where the thickness of the succession of alternating green, red, or grey laminated radiolarite and silicified tuff can reach 6-8 m (Fig. 5, Vászoly P-5 core) and even more in western part of the Felsőorrs Basin in the proximity of the submarine high (Fig. 5, Aszófó Af-2 core).

The Upper Ladinian sequence is made up by cherty nodular limestones of the Buchenstein Formation. They are characterized by bioclastic wackestone textures with plenty of calcite-filled moulds of radiolarians and juvenile specimens and fragments of thin-shelled bivalves (Fig. 7d). Posidonia and Halobia coquinas occur in the uppermost part of the Ladinian succession (Fig. 8). This bed-set is overlain by lowermost Carnian cherty limestones also of pelagic basin facies (Füred Limestone).

\section{Discussion}

\section{Interpretation of the depositional environments}

Litho- and biofacies characteristics and their space and time distribution in the studied successions provide the basis for interpretation of the depositional environments and basin evolution. However, the paleogeographic position of the study area on the margin of the Neotethys
260

261

262

263

264

265

266

267

268

269

270

271

272

273
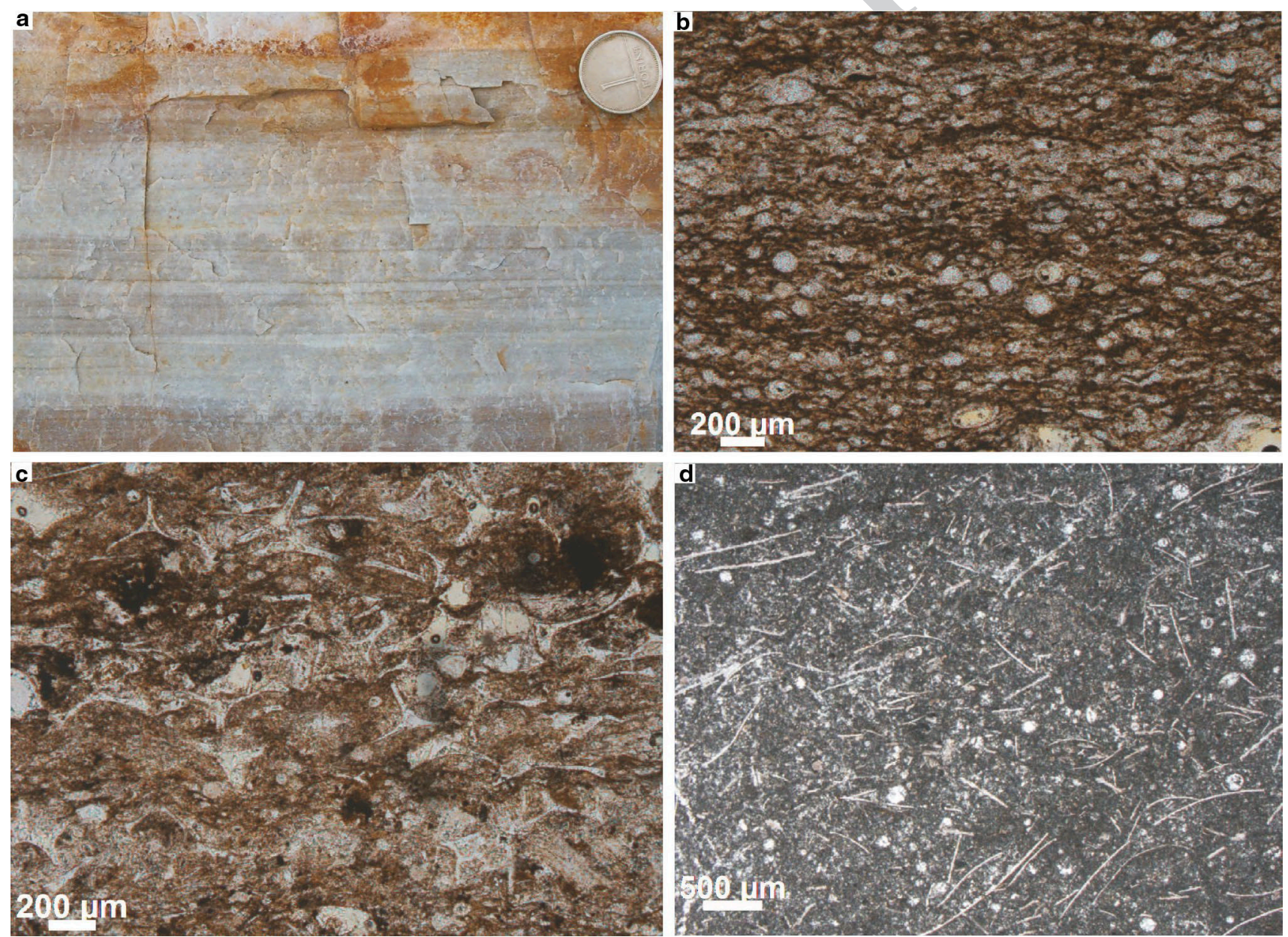

Fig. 7 Laminitic radiolarite, lower part of the Buchenstein Formation: a macroscopic image; Vászoly, Öreg Hill (N46 $\left.55^{\prime} 48.4^{\prime \prime} \mathrm{E} 17^{\circ} 46^{\prime} 57^{\prime \prime}\right)$. Photomicrographs on radiolarites: b, c radiolarian wackestone/packstone with silicified matrix, Dör- gicse (N46 $\left.54^{\prime} 47 \cdot 2^{\prime \prime} \mathrm{E} 17^{\circ} 44^{\prime} 17 \cdot 4^{\prime \prime}\right)$. d Photomicrograph of bioclastic wackestone with fragments of thin-shelled bivalves and radiolarians (calcite-filled moulds), upper part of the Buchenstein Formation, Vászoly, Öreg Hill (N46 $\left.55^{\prime} 41.8^{\prime \prime} \mathrm{E} 17^{\circ} 47^{\prime} 01^{\prime \prime}\right)$

\begin{tabular}{|llll|} 
Journal : Large 10347 & Dispatch : 29-6-2017 & Pages : 17 \\
Article No : $\mathbf{5 0 4}$ & $\square$ LE & $\square$ TYPESET \\
MS Code : FACI-D-16-00067 & $\square \quad$ CP & $\square \quad$ DISK \\
\hline
\end{tabular}



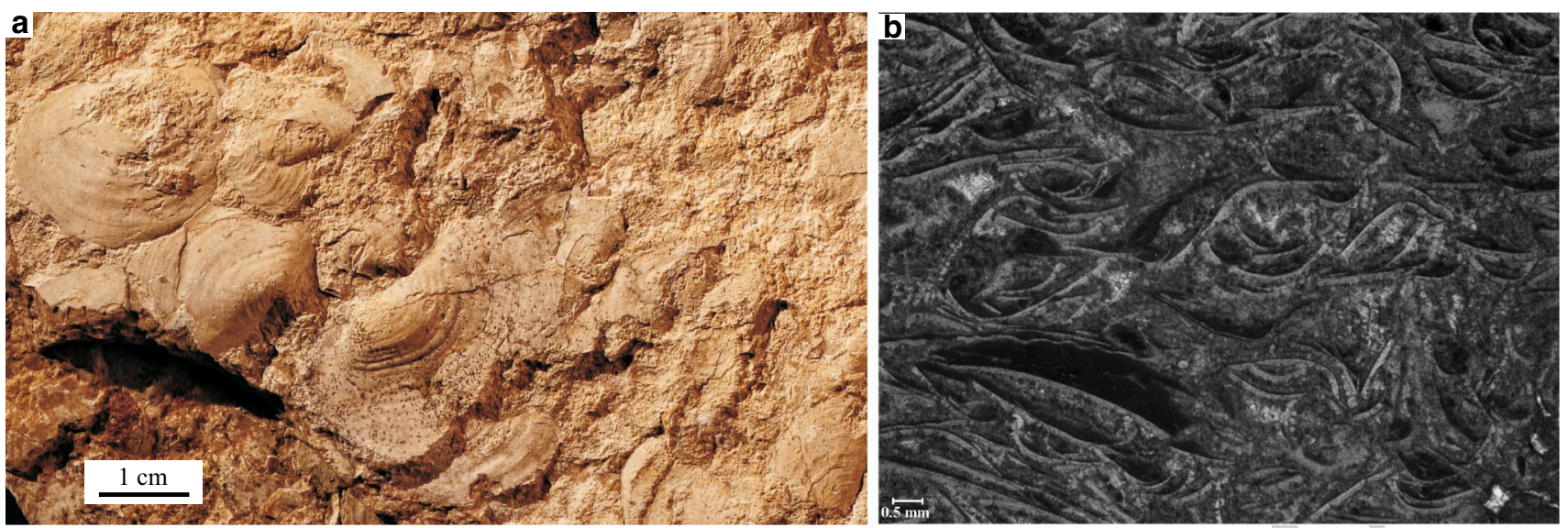

Fig. 8 Posidonia coquina in the upper part of the Buchenstein Formation (uppermost Ladinian), Vászoly, Öreg Hill $\left(\mathrm{N} 46^{\circ} 55^{\prime} 53.7^{\prime \prime} \mathrm{E} 17^{\circ} 46^{\prime} 28.9^{\prime \prime}\right)$. a Macroscopic image on a bedding

Ocean and the timing of the formation of the sequences at the initial stage of the ocean-opening must also be taken into account. In the Pelsonian, as a consequence of the coeval Neotethys rifting, the previously existing carbonate ramp disintegrated along normal faults. Rapidly subsiding basins were developed whereas shallow-marine carbonate deposition continued on the elevated blocks. The Tagyon Platform was one of these elevated bocks (Budai and Vörös 1992, 1993); a small isolated platform within a relatively large basin, which was probably only partly separated by submarine topographic highs from the open ocean. Acceleration of the tectonic subsidence and probably a coeval eustatic sea-level rise (Gianolla and Jacquin 1998) may have resulted in the drowning of this platform in the Late Illyrian (Budai and Haas 1997; Budai and Vörös 2006).

From the Pelsonian to the Late Illyrian, continuous deepening resulted in pelagic cherty carbonate deposition in the Felsőörs Basin, with ammonoids, conodonts, radiolarians, fragments of thin-shelled bivalves (Szabó et al. 1980; Kovács 1993; Dosztály 1993), and a specialized deep-sea ostracod fauna in the upper part of the sequence (Kozur 1970; Monostori 1995; Monostori and Tóth 2013). In the neighborhood of the submarine high, the lower part of the Ladinian succession is predominantly made up of radiolarite. On the Tagyon High, after an about 2-Ma-long gap (Budai and Vörös 2006), the Pelsonian platform carbonates were overlain by Late Illyrian pelagic carbonates with highly diverse ammonoid and radiolarian faunas and abundant thin-shelled bivalves. Ammonoid assemblages (Vörös 1996, 2002) and specialized ostracods (Monostori 1991) indicate water depths of some hundreds of meters. In the north-eastern part of the paleohigh, the drowning surface is covered by a phosphoritic crust and the overlying plane. b Photomicrograph of bioclastic wackestone with massive occurrence of thin-shelled bivalves

condensed bed set contains phosphoritic hardgrounds and phosphorite-impregnated layers. The basal part of the Ladinian is also characterized by the predominance of radiolarians in this area.

\section{Fossil diversity and abundance}

Radiolarians show high diversity almost everywhere in the Middle Anisian to Ladinian sequence of the Balaton Highland. Dosztály $(1991,1993)$ reported 50-70 species from several drilled cores and outcrops of the area. However, radiolarians appear in rock-forming quantity only on the top of the submarine Tagyon High and in the adjacent part of the coeval Felsöörs Basin (Figs. 3, 5).

Benthic faunas of the submarine high contain a moderately rich brachiopod assemblage. Bed by bed collection of the $\mathrm{P}-11 \mathrm{a}$ trench yielded more than 500 specimens of 14 taxa (Vörös and Pálfy 1989). However, after a Middle Anisian peak, the diversity of this group decreased during the Late Illyrian in the Balaton Highland (Vörös 2009) probably in connection with a relative sea-level rise (Budai and Vörös 1993).

Bivalves show low diversity with seven taxa (Vörös 2009). However, they are very abundant locally in distinct horizons, forming Daonella and Posidonia coquinas (Fig. 8) within the Vászoly Formation and even in the upper part of the Buchenstein Formation (Szabó 1972; Budai et al. 1999b). Daonella shell-beds were reported by Vörös and Pálfy (1989) from Bed 4 of trench P-11a, close to one of the major phosphoritic horizons of the section.

Triassic ammonoid fauna of the Balaton Highland reaches its highest diversity during the Late Illyrian and this conforms the global diversity curve as well (Vörös 2009, 2014).

\begin{tabular}{l|lll|} 
Journal : Large $\mathbf{1 0 3 4 7}$ & Dispatch : 29-6-2017 & Pages : $\mathbf{1 7}$ \\
Article No : $\mathbf{5 0 4}$ & $\square \quad$ LE & $\square$ TYPESET \\
MS Code : FACI-D-16-00067 & $\square \quad$ CP & $\square$ & DISK \\
\hline
\end{tabular}




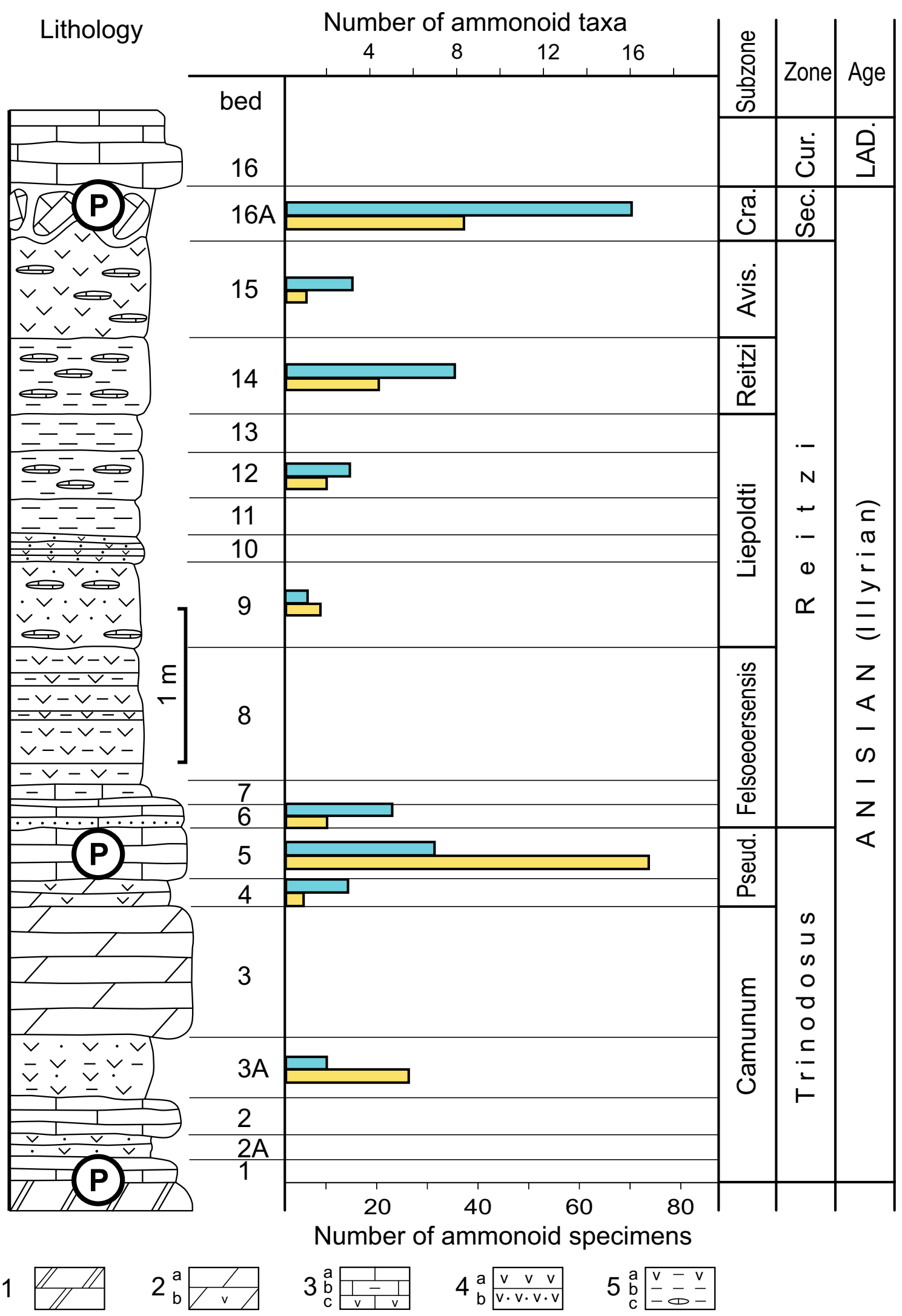


4Fig. 9 Stratigraphic column of P-11a trench (N46 $55^{\prime} 44.7^{\prime \prime} E 17^{\circ} 47^{\prime} 05.5^{\prime \prime}$ ), Vászoly, Öreg Hill (after Vörös and Pálfy 1989 and Vörös 1998) showing ammonoid diversity (number of taxa: blue) and abundance (number of specimens: yellow). 1 Platform dolomite; 2 Dolomitized basinal limestone (a) with volcanoclastic content (b); 3 hemipelagic limestone (a) with clay (b) or volcanoclastic content (c); 4 volcanic tuff (a) and lapilli tuff (b); 5 weathered clayey tuff (a) and clay (b) with limestone nodules (c). Avis. Avisianum, Cra. Crassus; Cur. Curionii; Lad. Ladinian; $P$ phosphatized layers; Pseud. Pseudohungaricum; Sec. Secedensis

It was demonstrated that ammonoids showed several pulses of diversification in the course of the Triassic, and that the second highest peak of generic richness in the history of Triassic ammonoids appeared in the Late Anisian (Tozer 1981; Brayard et al. 2009; Vörös 2014).

Detailed analysis of the temporal and spatial changes in generic richness and turnover rates of Middle Triassic ammonoid genera showed that the latest Anisian (Late Illyrian) peak of ammonoid diversity was particularly prominent in the western Neotethys Ocean (Vörös 2014).

The present study, focused on the Late Illyrian submarine Tagyon High, brought a new element in the paleoenvironmental interpretation. The ammonoid fauna collected here (from several sections and localities of the Öreg Hill) is extremely diverse (Vörös 1998); according to the ongoing revision, the 330 specimens, collected here, represent 48 taxa. This diversity peak, recorded in the uppermost Illyrian beds (Reitzi + Secedensis Zones) at the Tagyon High, fits well to the global/regional model of diversity dynamics summarized above (Vörös 2014). However, it is remarkable that the accumulation of the highly diverse ammonoid fauna is mostly connected to phosphoritic hardgrounds and phosphorite-impregnated layers in many places of the Öreg Hill. This relationship is definitely proved in the section of $\mathrm{P}-11 \mathrm{a}$ trench (Fig. 9). Here, the phosphorite content of the limestones (labeled P in Fig. 9) is high in Bed 5 (Trinodosus Zone, Pseudohungaricum Subzone) and in Bed 16/A (Secedensis Zone), where phosphorite occurs in distinct lenses. The peaks of abundance and taxic diversity of the ammonoids correspond well to the phosphate enrichments (Fig. 9). Since phosphorus is one of the major limiting nutrients, the above relationship can be interpreted as a further argument for the nutrient-controlled increase of ammonoid diversity recorded on the Tagyon High.

Radiolarians are the most common microfossils both in the Pelsonian to Ladinian basinal succession and the Late Illyrian to Ladinian drowning sequence of the submarine high. An evolutionary burst of this group was recognized in the Middle Triassic all over the world, when the number of families increased from 18 to 56 after the "chert gap", which followed the crisis of the end-Permian event (De Wever et al. 2003). This global trend was more pronounced on the western Neotethys margin than elsewhere.

In the modern oceans, radiolarians are most abundant and show the greatest diversity between 100 and $500 \mathrm{~m}$ depth in the tropical seas (De Wever et al. 2014). They are considered to be indicators of high productivity of the surface waters (De Wever and Baudin 1996; De Wever et al. 2014). Since productivity depends on the fertility controlled by the presence of the limiting nutrients (e.g., P, N, Si), the radiolarians are also indicators of the fertility. Radiolarians are abundant in the modern ocean where and when the nutrients are available (Seibold and Berger 1993; Baumgartner 2013; De Wever et al. 2014). For a sustained boom of radiolarians and, consequently, the production of a large amount of radiolarian tests, a continuous supply of the limiting nutrients to the near-surface water is needed. In recent studies, two options are usually considered for this: fluvial input from terrestrial sources and recirculation from decaying organic matter via upwelling (Baumgartner 2013; De Wever et al. 2014). However, due to common abundance of radiolarians in pyroclast-bearing successions, the role of input of volcanic dust in fertilization of sea-surface was also put forward (Lin et al. 2011; Abdi et al. 2016).

\section{Paleogeography and paleoclimate}

Based on paleomagnetic data, the Transdanubian Range was located around $18^{\circ} \mathrm{N}$ in the Middle Triassic (Brack et al. 1999; Feist-Burkhardt et al. 2008). As a consequence of juxtaposition of large continental and oceanic masses in the equatorial belt, monsoon-influenced climate regime existed in the Tethyan realm from the Late Paleozoic to the Late Jurassic (Parrish et al. 1979; Parrish and Curtis 1982; Kutzbach and Gallimore 1989; Parrish 1993; Preto et al. 2010). Since the intensity of the monsoonal circulation depends on the size of Pangea and the contrast between the continental domains on the northern and the southern sides of the equator, the "megamonsoonal" circulation reached maximum strength in the Triassic (Parrish 1993).

In the mid-Triassic, the Transdanubian Range was situated on the eastern rifted shelf of Pangea, near the western termination of the westward propagating Neotethys Ocean (Fig. 10a). In a wide external belt of the ocean margin, smaller and larger carbonate platforms were developed on the uplifted blocks, which were surrounded by deeper basins. Our study area was one of the submarine highs about a hundred kilometers from the Neotethys continental slope and hundreds of kilometers distance from the dry land of Pangea (Fig. 10b). Considering this paleogeographic setting, and also taking into account the reconstructed megamonsoon-related relatively dry (semi-arid) climate along the eastern Pangea margin (Parrish 1993; Haas et al. 2012),
407 


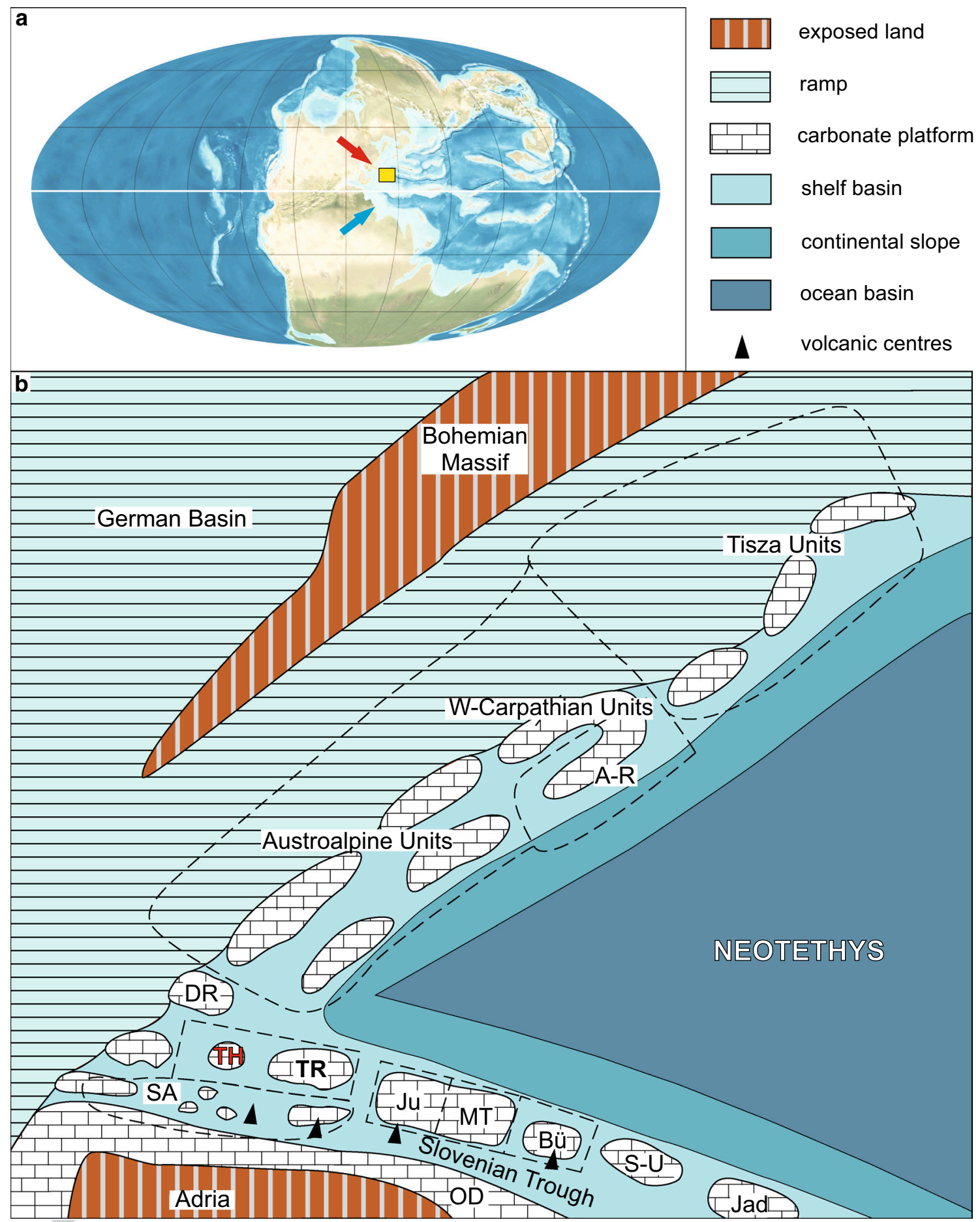

Fig. 10 Paleogeographic reconsruction for the Middle Triassic (a) after Blakey (http://jan.ucc.nau.edu/rcb7/mollglobe.html). Arrows show the wind direction during winter monsoon on the northern (red) and on the southern hemisphere (blue). The yellow rectangle shows the western part of the Neotethys (b) with the position of the Trans- terrestrial influx of nutrients (Caribbean River Plume Model of Baumgartner 2013), as main factor controlling the fertility, is improbable in this case. This concept is danubian range unit (TR) and the Tagyon High (TH), after Haas et al. 2004. AR Aggtelek-Rudabánya units, Bü Bükk unit, DR Drau range, Jad Jadar block, Ju Julian unit; SA South-Alpine units; $S-U$ Sana-Una unit; $M T$ mid-Transdanubian unit; $O D$ Outer Dinarids

supported by the results of the LA-ICP-MS analyses of the fine-grained CFA crystals of the phosphorite layers. The lack of correlation between redox-sensitive proxies, such as

\begin{tabular}{l|lll|} 
Journal : Large $\mathbf{1 0 3 4 7}$ & Dispatch : 29-6-2017 & Pages : $\mathbf{1 7}$ \\
Article No : $\mathbf{5 0 4}$ & $\square \quad$ LE & $\square$ TYPESET \\
MS Code : FACI-D-16-00067 & $\square \quad C P$ & $\square$ & DISK \\
\hline
\end{tabular}




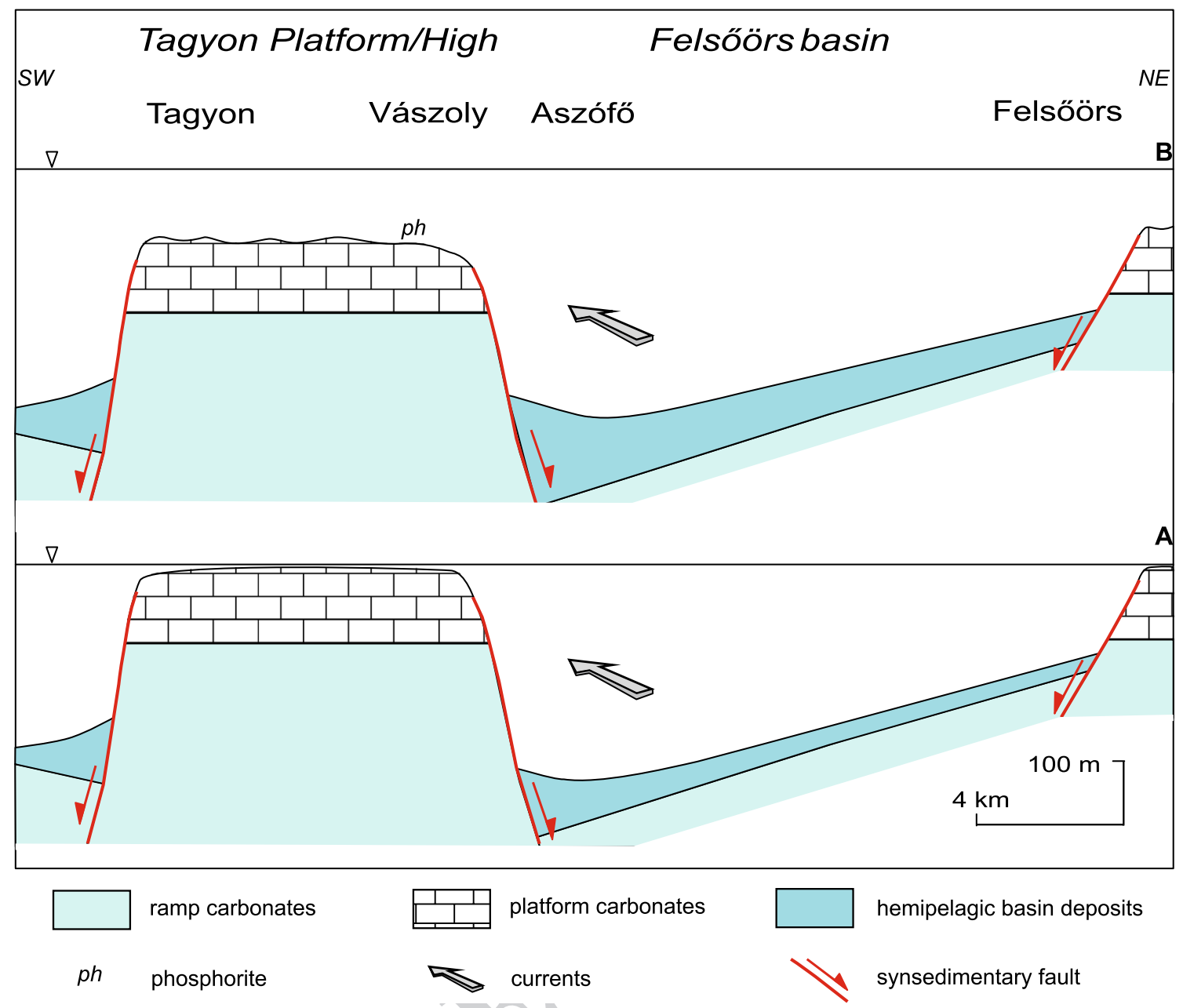

Fig. 11 Paleoenvironmental models for the Pelsonian Tagyon Platform (a) and the submarine high after its drowning during the Late Illyrian (b). ph phoshorite accumulation. The arrow indicates the

$\mathrm{Th} / \mathrm{U}$ and $\mathrm{Th} / \mathrm{V}$, suggest the absence of detrital influx (Molnár et al. 2016). However, the monsoon-controlled seasonal upwelling model (De Wever et al. 1994; 2014) seems to be applicable (Figs. 10, 11).

Latitude-normal position of a supercontinent (Pangea) and existence of a meridional ocean in the equatorial belt (Tethys) were responsible for the establishment of the megamonsoonal circulation pattern (Parrish 1993). This setting of the supercontinent destructed the zonal circulation and the equatorial warm ocean enhanced the monsoon effect triggered by the difference in the rate of heating of sea and land. The summer sun heats the land faster than the water and accordingly the wind blows from sea to continent, and conversely, the wind blows from the continent toward sea in winter. This means that our region may have been subject to south-eastward winds in the winter (from the higher latitude land masses of the northern hemisphere) and north-eastward winds in direction of topography-controlled currents carrying nutrient-rich water from the upwelling zone of the shelf margin

the summer (from the higher latitude land masses of the southern hemisphere) (Fig. 10a). The "megamonsoon"driven seasonally intense eastward winds forced the surface waters to move offshore and this may have caused upwelling of nutrient-rich subsurface waters along the continental slope and pumped the cold, oxygen-depleted, and fertile water through interplatform seaways into the internal parts of the shelf. The current direction on the shelf may have been mostly controlled by the segmented topography of the sea floor.

A modern example for the monsoon-related seasonal regional upwelling was observed in the Somalia and Owen basins, NW Indian Ocean, off Arabia (De Wever and Baudin 1996; DeWever et al. 2014). The upwelling-triggered nutrient transport resulted in high surface-water productivity facilitating the proliferation of radiolarians in these narrow basins, which are located behind platforms and whereby are partially restricted from the open ocean (De

\begin{tabular}{|l|ll|}
\hline Journal : Large 10347 & Dispatch : 29-6-2017 & Pages : 17 \\
Article No : $\mathbf{5 0 4}$ & $\square$ LE & $\square$ TYPESET \\
MS Code : FACI-D-16-00067 & $\square \quad$ CP & $\square$ DISK \\
\hline
\end{tabular}


Wever and Baudin 1996). However, it must be emphasized that the effect of the Triassic megamonsoon must have been much more pronounced than that of the present-day Indian monsoon.

An explosive peak of ammonoid diversity in the western Neotethys Ocean during the Late Illyrian can be interpreted in terms of major changes of two regional environmental factors: the high fertility and related enhanced primary productivity in the pelagic environments and the presence of nearby drowned and/or active carbonate platforms. The above-discussed nutrient availability may have favored the diversification of the ammonoids. Drowned platforms and margins of active carbonate platforms might have provided habitat diversification with vacant niches; the microbial mats, as primary producers, supplied suspended organic matter for the higher trophic levels and eventually for the ammonoids (Vörös 2014).

A large amount of pelagic larval or juvenile specimens of thin-shelled bivalves ("filaments") commonly co-occur with radiolarians in the studied formations of the Tagyon High and coquina beds of thin-shelled bivalves also occur (Fig. 8). Triassic flat clams often inhabited environments near the oxygen minimum boundary and formed monospecific fossil assemblages in organic-rich laminated deposits (McRoberts 2010). Massive occurrence of the thin-shelled bivalves in organic-rich formations was reported from upwelling zones: Halobia and Monotis occur in rockforming quantities in the Triassic phosphorite-bearing Shublik Formation in Alaska (Parrish et al. 2001). In the basins under the influence of the monsoon upwelling, the deposition of the pelagic carbonates, rich in radiolarians and thin-shelled bivalves, commenced already in the Late Pelsonian of the Balaton Highland (Vörös et al. 2003). Following models on the genesis of phosphatic sediments by Föllmi et al. (1994) and Glenn et al. (1994), we conclude that, in addition to the eustatic sea-level rise and the acceleration of the tectonic subsidence of the Felsőörs Basin during the Late Illyrian (Fig. 11), the high productivity (mesotrophic to eutrophic conditions) may have also contributed to the drowning of the Tagyon Platform. After drowning, the top of the submarine high might be affected by high-energy currents hampering the sediment accumulation for some time. Phosphoritic crust on the drowning surface was formed during this period probably with microbial mediation (Föllmi 1996). Later on, relative sealevel changes governed mostly by intermittent subsidence of the Tagyon High may have controlled the rate of sedimentation, the interruption of the accumulation, and the related hardground development. The current activity probably decreased during the high sea-level periods allowing the deposition. By contrast, it may have increased during the sea-level lowstands leading to winnowing and thereby condensation and hardground formation commonly with phosphoritization, i.e., formation of phosphorite grains, oncoids, crusts, and phosphorite impregnated horizons. Very low sediment accumulation rate and lithified substrate in fertilized water may have substantially promoted the phosphogenesis from sea-water derived phosphate (Föllmi 1996). This is confirmed by the mostly super-chondritic (approximately 47) Y/Ho ratio. In this context, it is worth mentioning that phosphorite horizons were observed only in the NE part of the Tagyon High. This asymmetric distribution pattern seems to confirm our concept on the fundamental role of the current direction in the phosphogenesis (Fig. 11).

Reflecting high productivity of the near-surface water, these carbonates deposited during the high sea-level usually contain a relatively high amount of organic matter. The $\mathrm{Th} / \mathrm{U}, \mathrm{V} / \mathrm{Sc}, \mathrm{V} / \mathrm{Cr}$, and $\mathrm{Ni} / \mathrm{Co}$ ratios also indicate reducing (anoxic) conditions (Molnár et al. 2016). Early diagenetic partial dolomitization of some of these beds can be related to bacterial sulfate reduction and methanogenesis, which may have taken place in the organic-rich carbonate sediments as organogenic dolomitization (Meister et al. 2007; Mazzullo 2000). The organogenic dolomitization model was also applied for interpretation of the genesis of the Late Anisian-Ladinian dolomite associated with organic carbon-rich shale in the intraplatform Monte San Giorgio Basin, southern Switzerland (Meister et al. 2013).

Contemporaneous radiolarian-rich successions on the western Neotethys margin

Radiolarites and radiolarian-rich carbonates similar to that of the Balaton Highland can be recognized in several sedimentary complexes formed during the Middle to Late Anisian on various parts of the Neotethys shelf (Fig. 10). In the Žumberak Mts (Croatian part of the Mid-Transdanubian Unit), Pelsonian platform carbonates are unconformably overlain by a fine-grained siliciclastic sequence containing volcanic tuffs and radiolarian cherts of Late Illyrian age (Gorican et al. 2005). In the Dinarids (e.g., in the Zlatibor Mts, and in the High Karst Nappe) the drowning of the Steinalm Platform took place in the Late Pelsonian (Bulog Limestone) and this was followed by a radiolarite event in the Late Illyrian (Gawlick et al. 2012; Sudar et al. 2013). In the Julian Alps, the Contrin Platform is overlain by red nodular radiolarian-rich pelagic limestone (Loibl Fm), the drowning event is dated as Late Illyrian (Pseudohungaricum Subchron, Celarc et al. 2013). In the Carnic Alps and in the eastern Dolomites, the irregular truncated surface of the Middle Anisian platforms is overlain by Late Anisian radiolarian limestones and marls of the Bivera Formation (Farabegoli and Guasti 1980; Farabegoli and Levanti 1982; Farabegoli et al. 1984). In the area of the western

\begin{tabular}{l|lll|} 
Journal : Large $\mathbf{1 0 3 4 7}$ & Dispatch : 29-6-2017 & Pages : $\mathbf{1 7}$ \\
Article No : $\mathbf{5 0 4}$ & $\square \quad$ LE & $\square$ TYPESET \\
MS Code : FACI-D-16-00067 & $\square \quad C P$ & $\square$ & DISK \\
\hline
\end{tabular}


Dolomites, the Contrin Platform is sharply overlain by a radiolarian-bearing, organic-rich laminated limestone succession (Plattenkalk Mb of the Livinallongo Fm). Here, the drowning is dated as latest Illyrian Avisianum Subchron (De Zanche et al. 1993; Gianolla and Jacquin 1998).

On the northern side of the Neotethys shelf (Fig. 10), the Middle Triassic radiolarite event was associated with the "Reifling event" (sensu Schlager and Schöllenberger 1974). In the Northern Calcareous Alps, the hardground on the upper surface of Pelsonian Steinalm Platform is overlain by cherty limestones alternating with thin silty marls (lower member of Reifling Fm). The drowning happened during the Late Pelsonian (Lein et al. 2012).

The Reifling event was also identified in the Aggtelek Hills (Silica Nappe) where the drowning surface of the Steinalm Platform is overlain by the red micritic filamentrich radiolarian Schreyeralm Limestone and radiolarite layers (Péró et al. 2015). In the Middle Triassic sequence of the Rudabánya Hills, the Upper Anisian Schreyeralm-type pelagic limestone abruptly overlies the Pelsonian Steinalm Platform (Kovács in Haas et al. 2004). The drowning was dated by an ammonoid assemblage of Late Illyrian age (Camunum and Pseudohungaricum subchrons) (Vörös 2010). This was followed by a radiolarite event represented by laminated red or dark-grey radiolarite (Szárhegy Fm) of Fassanian age.

\section{Conclusions}

In the middle part of the Balaton Highland, the Middle Anisian (Pelsonian) platform carbonates are directly overlain by a condensed pelagic carbonate bed set with phosphorite horizons and a diverse ammonite fauna that is followed by radiolarian-rich carbonates locally with radiolarite interbeds. Based on interpretation of previous observations and our new studies, we suggest that these features are controlled partly by regional factors related to the onset of opening of the Neotethys Ocean and local factors of the bottom topography and related current activity, which may also be connected with the ocean opening.

The Middle Triassic basin evolution of the western Neotethys realm, which includes the Transdanubian Range Unit and within it the Balaton Highland area, was mostly governed by the westward propagation of the Neotethys, which led to the establishment of an extensional tectonic regime and segmentation of the previously formed extensive marginal ramp. In the newly formed marginal basins, which were in direct connection with the ocean basin, radiolarian-rich siliceous carbonate sedimentation prevailed. This indicates high fertility of the surface waters that can be interpreted by the application of the monsoon-derived upwelling model (De Wever et al. 2014). Additionally, the coeval volcanic tuff input might also have contributed to the fertilization.

In the study area, as a result of the tectonically controlled segmentation, a small isolated platform (Tagyon Platform) was formed in the Pelsonian. Accelerated subsidence of this block accompanied by a eustatic sealevel rise in the Late Illyrian caused the drowning of this platform (Tagyon High from this time onwards), but the eutrophic surface water conditions may have also contributed to the drowning (Fig. 11). The asymmetry in the distribution of the phosphoritic deposits (restriction of the phosphorite horizons to the NE part of the Tagyon High) and the thickness pattern of the radiolarite (the maximum thickness in the NE part of the high and in the adjacent part of the basin) suggest local control, i.e., effect of wind-driven currents along the windward margin of the submarine high.

The segmented sea-floor topography together with the high-fertility surface water conditions may have provided food supply and favorable habitats for the ammonoids which adapted to various ecological conditions. Diversification of this group is attributed mostly to these factors.

In our case study, a critical period of the Middle Triassic evolution of the Balaton Highland area was discussed. We presented examples from other units of the western Neotethys margin where more or less similar contemporaneous evolution was reported (Dinarides, Southern Alps, Northern Calcareous Alps, Inner West Carpathians). This similarity underlines the importance of the regional controlling factors such as the establishment of an extensional tectonic regime and related marginal basin formation; monsoondriven upwelling and related high surface water productivity. However, local factors (i.e., sea-floor topography, volcanic activity), overprinting the regional ones, may have also played an important role in controlling the sedimentation during the Middle Triassic.

Acknowledgements The authors are grateful to József Pálfy, Peter Brack, and the Editor-in Chief Axel Munnecke for the careful and critical review of the manuscript and for their useful suggestions. The present scientific contribution is dedicated to the 650th anniversary of the foundation of the University of Pécs, Hungary. The University Centre for Applied Geosciences (UCAG) is thanked for the access to the Eugen F. Stumpfl Electron Microprobe Laboratory (Leoben). The LA-ICP-MS measurements were performed with the support of the University of Göttingen.

\section{References}

Abdi A, Gharaie MHM, Bádenas B (2016) Radiolarian productivity linked to climate condition during the Pliensbachian-Aaalenian in the Kermanshah Basin (West Iran). Facies. doi:10.1007/ s10347-016-0481-9

\begin{tabular}{l|lll|} 
Journal : Large $\mathbf{1 0 3 4 7}$ & Dispatch : 29-6-2017 & Pages : $\mathbf{1 7}$ \\
Article No : $\mathbf{5 0 4}$ & $\square \quad$ LE & $\square$ TYPESET \\
MS Code : FACI-D-16-00067 & $\square \quad$ CP & $\square$ & DISK \\
\hline
\end{tabular}


Baumgartner PO (2013) Mesozoic radiolarites-accumulation as a function of sea surface fertility on Tethyan margins and in ocean basins. Sedimentology 60:292-318

Brack P, Rieber H, Urlichs M (1999) Pelagic successions in the Southern Alps and their correlation with the Germanic Middle Triassic. Zbl Geol Palaont I(7-8):853-876

Brayard A, Escarguel G, Bucher H, Monnet C, Brühwiler T, Goudemand N, Galfetti T, Guex J (2009) Good genes and good luck: ammonoid diversity and the end-Permian mass extinction. Science 325:1118-1121

Budai T (1992) Middle Triassic formations of the Balaton Highland and of the Southern Alps: stratigraphic correlation. Acta Geol Hung 35:217-236

Budai T, Haas J (1997) Triassic sequence stratigraphy of the Balaton Highland, Hungary. Acta Geol Hung 40:307-335

Budai T, Vörös A (1992) Middle Triassic history of the Balaton Highland: extensional tectonics and basin evolution. Acta Geol Hung 35:237-250

Budai T, Vörös A (1993) The Middle Triassic events of the Transdanubian Central Range in the frame of the Alpine evolution. Acta Geol Hung 36:3-13

Budai T, Vörös A (2006) Middle Triassic platform and basin evolution of the Southern Bakony Mountains (Transdanubian Range, Hungary). Riv Ital Paleontol Stratigr 112:359-371

Budai T, Csillag G, Dudko A, Koloszár L (eds) (1999a) Geological map of the Balaton Highland, 1:50 000. Hungarian Geological Institute Budapest, Budapest

Budai T, Császár G, Csillag G, Dudko A, Koloszár L, Majoros Gy (1999b) Geology of the Balaton Highland. Explanation to the Geological Map of the Balaton Highland, 1:50 000. Occasional Papers Hungarian Geological Institute 197

Celarc B, Gorican S, Kolar-Jurkovsek T (2013) Middle Triassic carbonate-platform break-up and formation of small-scale halfgrabens (Julian and Kamnik-Savinja Alps, Slovenia). Facies 59:583-610

Cs Péró, Velledits F, Kovács S, Blau J (2015) The Middle Triassic post-drowning sequence in the Aggtelek Hills (Silica Nappe) and its Tethyan context-first description of the Raming Formation from Hungary. Newsl Stratigr 48:1-22

De Wever P, Baudin F (1996) Palaeogeography of radiolarite and organic-rich deposits in Mesozoic Tethys. Geol Rundsch $85: 310-326$

De Wever P, O’Dogherty L, Caridroit M, Dumitrica P, Geux J, Nigrini C, Caulet JP (2003) Diversity of radiolarian families through time. Bull Soc Geol France 174:453-469

De Wever P, O’Dogherty L, Gorican S (2014) Monsoon as a cause of radiolarite in the Tethyan realm. C R Geosci 346:287-297

De Zanche V, Gianolla P, Mietto P, Siorpaes Ch, Vail P (1993) Triassic sequence stratigraphy in the Dolomites (Italy). Mem Sci Geol 45:1-27

Dosztály L (1991) Triassic radiolarians from the Balaton Upland. Annu Rep Hung Geol Inst 1989:333-355

Dosztály L (1993) The Anisian/Ladinian and Ladinian/Carnian boundaries in the Balaton Highland based on Radiolarians. Acta Geol Hung 36:59-72

Farabegoli E, Guasti M (1980) Anisian lithostratigraphy and paleogeography of M. Rite (Cadore, southeastern Dolomites). Riv Ital Paleontol Stratigr 85:909-930

Farabegoli E, Levanti D (1982) Triassic stratigraphy and microfacies of the Monte Pleros (Western Carnia, Italy). Facies $6: 37-58$

Farabegoli E, Levanti D, Perri MC, Veneri P (1984) M. Bivera Formation: an atypical Middle Triassic "Rosso ammonitico" facies from Southern Alps (Italy). Giorn Geol 46:33-46

Feist-Burkhardt S, Götz AE, Szulc J, Borkhataria R, Geluk M, Haas J, Hornung J, Jordan P, Kempf O, Michalik J., Nawrocki J,
Reinhardt L, Ricken W, Röhling HG, Rüffer T, Török Á, Zühlke R (2008) Triassic. In: McCann T (ed) The Geology of Central Europe 2:749-821

Föllmi KB (1996) The phosphorus cycle, phosphogenesis and marine phosphate-rich deposits. Earth Sci Rev 40:55-124

Föllmi KB, Weissert H, Bisping M, Funk H (1994) Phosphognesis, carbon isotope stratigraphy, and carbonate-platform evolution along the Lower Cretaceous Northern Tethyan Margin. Bull Geol Soc Am 106:729-746

Gawlick HJ, Gorican S, Missoni S, Lein R (2012) Late Anisian platform drowning and radiolarite deposition as a consequence of the opening of the Neotethys ocean (High Karst nappe, Montenegro). Bull Soc Geol France 183:349-358

Gianolla P, Jacquin T (1998) Triassic sequence stratigraphic framework of western European basins. SEPM Spec Publ 60:647-654

Glenn CR, Föllmi KB, Riggs SR, Baturin GN, Grimm KA, Trappe J, Abed AM, Galli-Oliver C, Garrison RE, Dyin A, Jeh C, Rohrich V, Sadaquah R, Schiderlowski M, Sheldon RE, Seigmund H (1994) Phosphorus and phosphorites: sedimentology and environments of formation. Eclogae Geol Helv 87:747-788

Góczán F, Oravecz-Scheffer A (1993) The Anisian/Ladinian boundary in the Transdanubian Central Range based on palynomorphs and foraminifers. Acta Geol Hung 36:73-143

Gorican S, Halamic J, Grgasovic T, Kolar-Jurkovsek T (2005) Stratigraphic evolution of Triassic arc-backarc system in northwestern Croatia. Bull Soc Geol France 176:3-22

Haas J, Budai T, Hips K, Krivánné Horváth Á (eds) (2004) Magyarország geológiája. Triász, ELTE Eötvös Kiadó, Budapest, p 384

Haas J, Budai T, Csontos L, Fodor L, Konrád G (2010) Pre-Cenozoic geological map of Hungary, 1:500 000. Hungarian Geological Institute Budapest, Budapest

Haas J, Budai T, Raucsik B (2012) Climatic controls on sedimentary environments in the Triassic of the Transdanubian Range (Western Hungary). Palaeogeogr Palaeoclimatol Palaeoecol 353-355:31-44

Haas J, Budai T, Győri O, Kele S (2014) Similarities and differences in the dolomitization history of two coeval Middle Triassic carbonate platforms, Balaton Highland, Hungary. Facies 60:581-602

Haas J, Hips K, Budai T, Győri O, Lukoczki G, Kele S, Demény A, Zs Poros (2016) Processes and controlling factors of polygenetic dolomite formation in the Transdanubian range: a synopsis. Int J Earth Sci. doi:10.1007/s00531-016-1347-7

Jones B, Manning DAC (1994) Comparison of geochemical indices used for the interpretation of palaeo-redox conditions in ancient mudstones. Chem Geol 111:111-129

Kiss J, Virágh K (1959) An uranium-bearing phosphatic rock in the Triassic of the Balaton Uplands around Pécsely. B Hung Geol Soc 89:85-97

Kovács S (1993) Conodonts of stratigraphical importance from the Anisian/Ladinian boundary interval of the Balaton Highland, Hungary. Riv Ital Paleontol Stratigr 99:473-514

Kovács S, Nicora A, Szabó I, Balini M (1990) Conodont biostratigraphy of Anisian/Ladinian boundary sections in the Balaton Upland (Hungary) and in the Southern Alps (Italy). Cour Forsch Senckenberg 118:171-195

Kozur H (1970) Neue Ostracoden-Arten aus dem obersten Anis des Bakonyhochlandes (Ungarn). Ber Naturwiss Innsbruck 58:384-428

Kutzbach JE, Gallimore RG (1989) Pangean climates: megamonsoons of the megacontinent. J Geophys Res 94(D3):3341-3357

Lein R, Krystyn L, Richoz S, Lieberman H (2012) Middle Triassic platform/basin transition along the Alpine passive continental margin facing the Tethys Ocean-the Gamsstein: the rise and fall of a Wetterstein Limestone Platform (Styria, Austria). J Alpine Geol 54:471-498

\begin{tabular}{llll|} 
Journal : Large 10347 & Dispatch : 29-6-2017 & Pages : $\mathbf{1 7}$ \\
Article No : $\mathbf{5 0 4}$ & $\square$ LE & $\square$ TYPESET \\
MS Code : FACI-D-16-00067 & $\square \quad$ CP & $\square$ DISK \\
\hline
\end{tabular}


Lin H, Hu C, Li YH, Ho TY, Fischer TP, Wong GTF, Wu FJ, Huang CW, Chu DA, Ko DS, Chen JP (2011) Fertilization potential of volcanic dust in the low-nutrient low-chlorophyll western North Pacific subtropical gyre: satellite evidence and laboratory study. Glob Bioiochem Cycles 25:GB1006

Lóczy L (1916) Die geologische Formationen der Balatongegend und ihre regionale Tektonik. Resultate der wissenschaftlichen Erforschung des Balatonsees 1(1), $716 \mathrm{p}$

Mandl G (1991) Über eine triadische Tiefwasserfazies (Radiolarite, Tonschifer) in der Nördlichen Kalkalpen-ein Vorbericht. J Geol B-A 134(2):309-318

Mazzullo SJ (2000) Organogenic dolomitization in peritidal to deepsea sediments. J Sediment Res 70:10-23

McRoberts ChA (2010) Biochronology of Triassic bivalves. Geol Soc Spec Publ 334:201-219

Meister P, McKenzie JA, Vasconcelos C, Bernasconi SM, Frank M, Gutjahr M (2007) Dolomite formation in the dynamic deep biosphere: results from the Peru Margin (ODP Leg 201). Sedimentology 54:1007-1032

Meister P, McKenzie JA, Bernasconi SM, Brack P (2013) Dolomite formation in the shallow seas of the Alpine Triassic. Sedimentology 60:270-291

Molnár ZS, Kiss BG, Zaccarini F, Dunkl I, Dódony I (2016) Formation conditions of two phosphorite occurrences from the Transdanubian Mountain range (Hungary). Abstract Book, European Mineralogical Conference, Rimini, p. 616

Monostori M (1991) Triadogigantocypris balatonica n. gen. n. sp.: a giant ostracode from the Hungarian Triassic. Neues Jahrb Geol P M 2:91-96

Monostori M (1995) Environmental significance of the Anisian Ostracoda fauna from the Forrás Hill near Felsőörs (Balaton Highland, Transdanubia, Hungary). Acta Geol Hung 39:37-56

Monostori M, Tóth E (2013) Ladinian (Middle Triassic) silicified ostracod faunas from the Balaton Highland (Hungary). Riv Ital Paleontol Stratigr 119:303-323

Parrish JT (1993) Climate of the supercontinent Pangea. J Geol 101:215-233

Parrish JT, Curtis RL (1982) Atmospheric circulation, upwelling and organic-rich rocks in the Mesozoic and Cenozoic Eras. Palaeogeogr Palaeoclimatol Palaeoecol 40:31-66

Parrish JT, Hansen KS, Ziegler AM (1979) Atmospheric circulation and upwelling in the Paleozoic, with reference to petroleum source beds (abs.). AAPG Bull 63:507-508

Parrish JT, Droser ML, Bottjer DJ (2001) A Triassic upwelling zone: the Shublik Formation, Arctic Alaska, USA. J Sediment Res 71:272-285

Preto N, Kustatscher E, Wignall PB (2010) Triassic climates State of the art perspectives. Palaeogeogr Palaeoclim Palaeoecol 290: $1-10$
Seibold E, Berger WH (1993) The sea floor. An introduction to marine geology. New York, Springer

Sudar M, Gawlick HJ, Lein R, Missoni S, Kovács S, Jovanovic D (2013) Depositional environment, age and facies of the Middle Triassic Bulog and Rid formations in the Inner Dinarides (Zlatibor Mountain, SW Serbia): evidence for Anisian break-up of the Neotethys Ocean. N Jahrb Geol Paleontol Abh 269:291-320

Szabó I (1972) Triász. In: Deák M (ed) Magyarázó Magyarország 1:200000-es földtani térképsorozatához, L-33-XII. Veszprém. Hungarian Geological Institute, Budapest

Szabó I, Kovács S, Gy Lelkes, Oravecz-Scheffer A (1980) Stratigraphic investigation of a Pelsonian Fassanian section at Felsőörs (Balaton Highland, Hungary). Riv Ital Paleontol Stratigr 85:789-806

Tozer ET (1981) Triassic Ammonoidea: classification, evolution and relationship with Permian and Jurassic forms. In: House MR, Senior JR (eds): The Ammonoidea. Systematics Association Special Volume, 18 , pp. $65-100$

Vörös A (1993) Redefinition of the Reitzi Zone at its type region (Balaton area, Hungary) as the basal zone of the Ladinian. Acta Geol Hung 36:15-31

Vörös A (1996) Environmental distribution and bathymetric significance of Middle Triassic ammonoid faunas from the Balaton Highland, Hungary. Fragm Mineral Palaeontol 18:5-17

Vörös A (1998) A Balaton-felvidék triász ammonoideái és biosztratigráfiája. Studia Naturalia 12

Vörös A (2002) Paleoenvironmental distribution of some Middle Triassic ammonoid genera in the Balaton Highland (Hungary). Abh Geol Bundesanstalt 57:479-490

Vörös A (ed), Budai T, Lelkes Gy, Kovács S, Pálfy J, Piros O, Szabó I, Szente I (2003) The Pelsonian Substage at the Balaton Highland (Middle Triassic, Hungary). Geol Hung ser Pal 55

Vörös A (2009) Local versus global effects on changes of fossil diversity: paleoenvironmental interpretation of Triassic faunas of the Balaton Highland (Hungary). Cent Eur Geol 52:343-358

Vörös A (2010) Late Anisian Ammonoidea from Szár-hegy (Rudabánya Mts); a Dinaridic-type fauna from North Hungary. Fragm Palaeontol Hung 28:1-20

Vörös A (2014) Ammonoid diversification in the Middle Triassic: examples from the Tethys (Eastern Lombardy, Balaton Highland) and the Pacific (Nevada). Cent Eur Geol 57:319-343

Vörös A, Pálfy J (1989) The Anisian/Ladinian boundary in the Vászoly section (Balaton Highland, Hungary). Fragm Mineral Palaeontol 14:17-27

Wignall PB, Twitchett RJ (1996) Oceanic anoxia and the end Permian mass extinction. Science 272:1155-1158

\begin{tabular}{l|lll|} 
Journal : Large 10347 & Dispatch : 29-6-2017 & Pages : $\mathbf{1 7}$ \\
Article No : $\mathbf{5 0 4}$ & $\square$ LE & $\square$ TYPESET \\
MS Code : FACI-D-16-00067 & $\square \quad$ CP & $\square$ DISK \\
\hline
\end{tabular}

